\title{
The Dutch East Indies Policy for The Plantation in
} \section{Java}

\author{
$1^{\text {st }}$ Max L. Tamon \\ History Education Department \\ Faculty of Social Science \\ Universitas Negeri Manado \\ Manado, North Sulawesi \\ maxtamon@unima.ac.id
}

\author{
$2^{\text {nd }}$ Meity Najoan \\ History Department \\ Faculty of Social Science Universitas \\ Negeri Manado \\ Manado, North Sulawesi \\ meitynajoan@unima.ac.id
}

\author{
$3^{\text {rd }}$ Yohanes Burdam \\ History Department \\ Faculty of Social Science \\ Universitas Negeri Manado \\ Manado, Indonesia \\ yohanesburdam@unima.ac.id
}

\author{
$4^{\text {th }}$ Agus Trilaksana \\ History Education Departement \\ Faculty of Sosial Sciences and Law \\ Universitas Negeri Surabaya \\ Surabaya, Indonesia \\ agustrilaksana@unesa.ac.id
}

\author{
$5^{\text {th }}$ Sri Mastuti Purwaningsih \\ History Education Departement \\ Faculty of Sosial Sciences and Law \\ Universitas Negeri Surabaya \\ Surabaya, Indonesia \\ srimastuti@unesa.ac.id
}

\begin{abstract}
This research aims to expound the background to what causes the implementation of enforcement planting system. To describe the impact that happened to Java community by applying the enforcement planting system. To explain the reaction appeared because of the enforcement planting system. The approach of this research is structualism or structualist. According to Christopher Lloyd (1993:187-192), Structural approach combines the basis of event with the basis of structural approach, that is to say the unique things (in the event approach) with the universal things ( social structure in structural approach ). It is also utilizing hermeneutic to explain causal factor, and story form to complete the analysis by benefiting concepts to build up theories or models (R.Z. Leirissa, 1999:48). The problem which has been examined by the first structural approach can be directed by the event, without overriding the structure that hosts the event itself: secondly, it is also can be directed from the social structure without vanishing the event which is the active substance; and thirdly, the ideal is point of the problem that hs been examined directs to the situation at once, either social structure or event( Lloyd,1993:187-192;R.Z.Leirissa,1999:48). The method of collecting data and data analysis utilize the historical method from Marc Bloch (1988:80); where collected data is grouped by the means of: (a) generalization, and or (b) categorization. These ways are utilized based on the concepts that become "Building material " from the theory to be the basic explanation of fact, which is 'collective action' theory from Charlles Tilly(1978:46-55), that the conflict happens because there is interest, that is organized to mobilize the exertion and fund which is result in the act of collectively, although there is pressure; and conflict theory from Lewis A. Cose r(1964:67-72), in one of the prepositions, that the conflict is happening for a long time because in both side especially the follower, doesn't know about the conflict purpose. According to the result of the research and discussion, it can be concluded that: The background of implementing the Dutch policy in the economic field throughout the enforcement planting system because of the lack of Dutch finances caused by the cost of expenditure in Diponegoro and Belgium war that had been separated from the Netherlands.
\end{abstract}

\section{Keywords-Policy, Government, Plantation}

\section{INTRODUCTION}

The rich soil can be used as the a place to plant different kinds of plants, this condition had been had by Indonesian making the development of the agriculture that produced the crop for the need of the sociaty such as cloves, nutmegs, pepper and others included in in the group of spices. The spices as the product of sale in XVI - XX century occupied the important role and the prise were expensive. It was not surprising that the areas that had been the center of spice producer were visited by the west.

The motive of the arrival of the Dutch, Portuguese and Spanish were different. Portuguese and Spanish were encouraged by three factors but the Dutch only two which is economic factor and adventure [1].

The interests of the dutch in indonesia are only economic and adventure while religion was not reckoned. It can be seen here that how ambitious the ducth was in order to control Indonesia. It was in the development of the indonesia, those who were firstly arrived to the nation were the portuguese and spanish, but the longest one who were stood still in Indonesia was Dutch.

Reference [2] explained that portuguesse were the dutch who inherited portuguesse's aspiration and strategy. The dutch brang organisation, weaponry, ships and better financial support also the combination between courage and atrocity. They almost reached of what portuguesse wanted but they did not successfully over taking the whole commerce of the spices in Indonesia.

Because of that, to be able to reach of what the dutch wanted, they used many efforts so that all the existence wealth can be controlled. To be able to control the Indonesian, which had already been calculated well, because of the natural resources in Indonesia were the source of huge profit and also could support the dutch prosperity. At the 
next development, after the dutch used the harmful way, it made the spices commerce got monopolized by the dutch.

In the beginning of XVII century, the economic field in Indonesia had already been controlled by the dutch and in this case VOC (Verenigde Oost Indische Compagnie). In the historical development, at December 311799 VOC were dissolved for having bankcrupty then all of its wealth were taken over by the Dutch government. For a while, the Dutch were still continuing the politic from VOC to get the benefit by collecting tribute from the local rulers. To collect to tribute, the forced labour has to be applied by the Dutch government. This policy the Dutch had been made were become burden to the Indonesian people. The governmental system thad had been driven was the indirect system, led by sultan or regent who was in charge to order. This system was still beneficial for the local rulers because the sovereignty was still claimed.

The governmental situation had the change caused by the development applied at the main country. In the year of 1808, Herman William Daendels arrived in Java island. His reign period in Indonesia included the eradication of corruption. To add the cash of the main country, they traded land to the private, but the result was not included to the pay office but it was spent for the personal need instead. For the effect of what Daendels had done, the government replaced him with Janssens.

Janssens' reign was not in the long term, because Java island was already under invasion by the british under the rule of Raffles who practiced the liberalism principle and various change was applied to advance the servitude land.

The policy that Raffles imposed was the continuance of the policy from Dirk Van Hogendorp in the end of XVII century, the freedom was tried to be given. But although the forced labour was eradicated but the the enforcement planting were still conducted by the community, so the profit will be received through the commerce. The governmental system thas had been running was directly where the Dutch kept in touch with the community themselves, while the ranking of sultan and regent had started to be reduced.

To kept the Java island controlled, Raffles created land rent system, with the purpose to give the community the freedom to try and not to be bounded to the chiefs or regent. The community has to compete in the commercial activity.

Reference [3] stated that the land rent system contained consequence that all the high economic activity was no longer organised by the chiefs, the lower and high leader and also regent with the bond of custom, but the free agriculture and free trade as well.

Free agriculture and free trade was difficult to be applied because those lost the influences of custom bond, but Raffles kept carry the land rent out. To make it keep running, the administration has to be complete so that the European employee could be increased more and the rise of residential system would reduce the regent's position. The land rent had been created by Raffles was continued by his substitute, even in the different situation. The most burdensome land rent was what had been applied by Van Den Bosch which was the enforcement land rent. The result of enforcement land rent had already given benfits to the main pay office. Nevertheless, to be able to apply the enforcement land rent or knownly as enforcement planting system, the victim would be sociaty.

The real colonialism period in Java history began in 1830. The dutch government for the first time were able to exploit and control the whole island. There was no serious challenge against their reign in the 20th century. The dutch was also available to involve directly to Java to the remote area. This political domination was finally success in whole Java in 1830 [2].

The policy that had been applied in 1830 gave impact to the development of plantations in Java for the applied regulation was not conducted well because of the various deviation made burdens to the Javanese. The suffering of the sociaty was reported to the dutch parliament and this was caused by the dutch itself, making the pro and contra to the policy, so that little by litte, the enforcement land rent had started to be eradicated. Then the prosperity of the sociaty had started to be the concern by the colonial government.

Furthermore, The dutch government released the agrarian law 1870 (Agrarische Wet 1870) which by mean was contained the basic rules as follows: (1). Governor general is not allowed to sell the land. (2). Governor general is allowed to rent the land according to the regulation arranged by the law. (3). According to the law, would be given lands by the legitimacy as long as it is not more than 75 whim. (4). Governor is not allowed to take the lands that is already released by the Indonesian people.

According to those explanations, the witter will examine on how the policy of the dutch government towards the development of plantaion in Java. The reason that caused the writter to be interest of the problem was the policy of the land rent was the continuation of Raffles' policy but in the different implementation. But the application of this land rent was giving benefit to sociaty by diversification of clan plant extensively in agriculture field, the result was oriented to comercial direction.

The problem in this research is formulated as follows: (1). What background that caused the implementation of enforcement plating system. (2). What impact that happened to Javanese community in terms of the aplication of enforcement planting system. (3). What reaction seen as the consequence of the application of enforcement planting system.

\section{RESEARCH METHODS}

The approach in this research is structurism or structural. According to reference [4], Structural approach combines the basis of event with the basis of structural approach, that is to say the unique things ( in the event approach ) with the universal things ( social structure in structural approach ). It is also utilize hermeneutic to explain causal factor, and story form to complete the analysis by benefiting concepts to build up theories or modelslei [5]. The problem which has been examined by the first structural approach can be directed by the event, without overriding the structure that hosts the event itself: secondly, it is also can be directed from the social structure without vanishing the event which is the active substance; and thirdly, the ideal is point of the problem that hs been examined directs to the situation at once, either social structure or event [4]; [5]. The method of collecting data and data analysis utilize the historical method from [6]; where collected data is grouped by the 
means of: (a) generalization, and or (b) categorization. These ways are utilized based on the concepts that become " Building material " from the theory to be the basic explanation of fact, which is 'collective action' theory from Charlles Tilly (1978) in [7] that the conflict happens because there is interest, that is organized to mobilize the exertion and fund which is result in the act of collectively, although there is pressure; and conflict theory, in one of the prepositions, that the conflict is happening for a long time because in both side especially the follower, doesn't know about the conflict purpose.

\section{RESULTS AND DISCUSSION}

The implementation of enforcement planting system that used the community farmland at that time with the prescriptive regulation, but in the implementation, the communuty rice field which was not included to be used on eventually used or the enforcement planting. This condition had contradiction with the defined regulation that the rice field of the community could not be used as the area for the enforcement planting.

Thereby, the status of javanese sociaty land at that time could not defensible, because at call it could be taken away to be the area of enforcement planting. Agraria politic in the colonial period was in conflict with the importence of the sociaty and the Indonesian country itself. In the implementation of colonial politic after the release of Agrarische wet in 1870, the foreign capital entered Indonesia in the wide-scale especially in Java island and Sumatra, the big plantations grew and stood. By the existence of this big plantation, the agraria structure became very complex. Almost all the fertile area especially in Java and Sumatra had been spread around the western rights for example the erfpacht ( kind of right of tenure by long lease ) which was packed within the custom right [8].

According to the above discussion, it is clear that oftenly the erpacht right was being in contradiction with the custom right, making the custom land was used to be the right of tenur by long lease.

In the period after the independence, it had been dualism of the land right to impel the emendations of Agrarische Wet 1870. By the legitimation of principle agraria law in 1960 created the abolition from the dualism of land right. On that account, in compliance with the article 7 UUPA 1960 not to the prejudice of public sake so that the ownership of the land and its control that overreach would not be allowed. Thereby there was the limitation in the use of land.

In Agrarische wet, the right of tenur by long lease oftenly obstruct the custom right dan the use of of land has the period of 75 yeas but by UUPA 1960 for the right of tenur by long lease is not more than 25 years and 35 years for the company, the period of time could be renewal to 25 years more if the long lease holder maintain his right and offer the renewal to the same lease hold land (Hasmonel dkk., 2001: 7.20).

According to the those explanations, it is clear that there is a different between Agrarische Wet and UUPA in 1960 about the right of tenur by long lease. If Agrarische Wet in the time limit of the used land for 75 years but by the renewal of UUP 1960, the use of land only around 25 years and it was going to be 35 years for the company and it can be renewal again by the long lease holder.

The Land use in the period of Dutch Indies and Indonesian government were different because of the difference of situation and condition, and also the regulation that had been applied was different. The difference were seen for the right of tenure by long lease, the dutch indies governmental period has its the right of long lease until 75 years, but it was 25 years in the reign of Indonesian government and could be renewal again by the long lease holder.

This time, there are lots of cases, that can be seen on Televion channel or in the newspaper about the land issues, where there is protest from the sociaty through demontration to refuse or ask the rule the president has released about the procurement of the land for public sake.

The release of President regulation in 36/2005 about the procurement of the land for public sake is the full authority of the president, But the house of representative will always clamp down on the implementation. The house of representative has to be consistent if there are parties who play in the interpretation of public sake beside of what has been arranged on President regulation, stated by Arbab Paproeka (Harian Umum Pelita, 1 Agustus 2005).

He admited that by the law number $5 / 1960$ about the basic of agraria, the individual right for the claimed land, but the provision of right to the land would not be making people or instance could maintain their land absolutely. In the article 6 UUPA mentioned that all the land rights have the social function which means that if it will be used for the public sake, that right has to be liberated. Extremely, the right will be eradicated (Harian Umum Pelita, 1 Agustus 2005).

According to the president regulation, the land right has been clearly arranged, but the individual right to the land will be released if the land is used for the public sake. Thereby, the basic law of the validation of the land right is clear and it has to be implemented by the Indonesian people.

Thereby, according to the Agrarische Wet regulation in 1870 until the released of UUPA in 1960 there were problems the sociaty had to face. The sociaty was treated unjustly for their lands. If their lands would be used for the public sake, they have to liberate it by getting the retribution that was not comparable with the prize of the land price.

\section{CONCLUSION}

According to the result of the research and discussion above, it can be concluded as follows: (1). The background of implementing the Dutch policy in the economic field throughout the enforcement planting system because of the lack of Dutch finances caused by the cost of expenditure in Diponegoro and Belgium war that had been separated from the Netherlands. The high cost of the expenditure effected the main pay office, making the Governor general Van Den Bosch to suggest the implementation of enforcement planting system. The regulation of enforcement planting actually was beneficial to the sociaty but it had been deviated by the poople who were taken the authority from the Netherlands making the suffer for the sociaty. The result of the system in the long term period was able to refill the emptiness of government pay office, so that the debt of VOC could be settled and at the 
same time there was development by the government. enforcement planting system created the inovation in the agriculture field and also Agraria commercially. (2). The effect of the implementation of the system for Netherlands in the economic field which is the refilling of the pay office in the short time period, while in the social field, the morality of the dutch employee was decreased to corruption. For Indonesia, the effect in the economic field which is the entry of money economic to the villages and the open of free work for the sociaty by being the factory worker and rent their horse-drawn cart to carry the stuff to the factory. In social field, it made th e status of the regents and their prestige stronger. (3). The implementation of enforcement planting system had been done by the dutch through proccesses whether inside the parliament or outside the parliament which had been pioneered by Eduard Douwes Dekker, Frans Van pe Putte, de Wall, etc. It made the government reformed the policy in the shadow land by implementing Agrarisch wet 1870 .

The suffer that the sociaty in the enforcement planting system had been around for is expected not to happen anymore, but rather through that suffer can make the precious experience in the development of the country.

\section{ACKNOWLEDGMENT}

We would like to say thanks to the Rector of Manado State University who has facilitated the research and writing of this article, also to our fellow research team and writers. Thanks also to the Committee of International Conference on Social Science (ICSS) and the Atlantis Press Publisher which has facilitated the publication of this article.

\section{REFERENCES}

[1] S. Kartodirdjo and D. Surjo, Sejarah perkebunan di Indonesia: kajian sosial-ekonomi. Aditya Media, 1991.

[2] M. C. Ricklefs, Sejarah Indonesia Modern, 1200-2004. Penerbit Serambi, 2005.

[3] D. H. Burger, "Sejarah Ekonomi Sosiologis II," Jakarta: Pradnya Paramita, 1962.

[4] C. Llyod, "The Structures of History." Oxford and Cambridge: Blackwell, 1993.

[5] R. Z. Leirissa, G. A. Manilet-Ohorella, and Y. B. Tangkilisan, Sejarah Perekonomian Indonesia. Departemen Pendidikan dan Kebudayaan RI, 1996.

[6] M. Bloch, The historian's craft. Manchester University Press, 1992.

[7] R. A. Mohl, "City and region: the missing dimension in US urban history," J. Urban Hist., vol. 25, no. 1, pp. 3-21, 1998.

[8] S. Mertokusumo, "Hukum dan Politik Agraria," Univ. Terbuka, Karunika, Jakarta, 1988. 